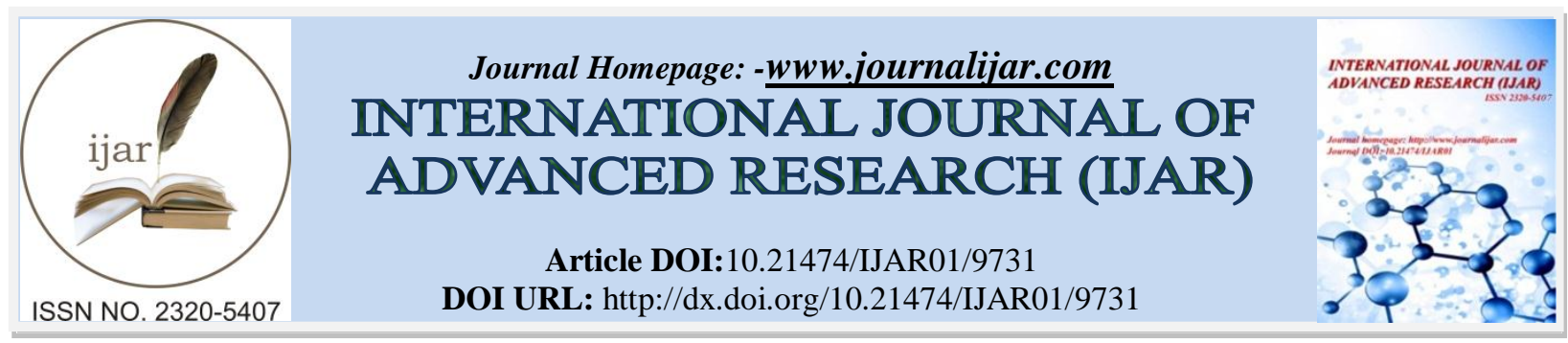

RESEARCH ARTICLE

\title{
A STUDY ON IDENTIFYING THE PRE-ANALYTICAL PHASE ERRORS LEADING TO BIOCHEMISTRY AND HEMATOLOGY SAMPLE REJECTION BY USING FMEA \& PARETO'S PRINCIPLE.
}

Ms. Golla Rachana and Dr. Manjunatha R.

\section{Manuscript Info}

Manuscript History

Received: 09 July 2019

Final Accepted: 12 August 2019

Published: September 2019

\begin{abstract}
Laboratory specialists have been demonstrated that $70 \%$ of errors occur in the pre-analytical phase which is an important service of laboratory medicine. If the occurrence of error is manmade then it can always be identified and reduced. As the hospital management needs to evaluate the quality of laboratory services by knowing the sample rejection rate. A descriptive study was conducted to investigate and reduce the rejection rate for the Biochemistry and haematology samples received in the clinical laboratory. A strategy used in the study for the source detection of Failure modes are a) Brainstorming, b) Fish-bone diagram, c) Pareto's chart, d) Failure Mode and Effect Analysis (FMEA) is an aid to calculate Risk Priority Number (RPN) that is the product of Occurrence Index (O.I), and Detectability Index (D.I). The total number of samples (both from OP \& IP-D) received in the laboratory during the study period from January 2018 to April 2019 is about 3, 81,452 samples. The total number of samples rejected by the laboratory is 182 $(0.047 \%)$. The highest rates according to Pareto's principle \& FMEA analysis are found for the failure modes sample clot, insufficient sample quantity, inappropriate sample Vacutainer/tube with RPN value of 48 , 36 and 30 respectively. Even though these RPN values are highest among all identified failure modes, they are less than $50(\mathrm{RPN}<50)$ which indicates that the processes involved are well controlled.
\end{abstract}

Copy Right, IJAR, 2019,. All rights reserved.

\section{Introduction:-}

The Scope of laboratory services in the hospital are mainly clinical biochemistry, clinical microbiology and pathology. The studies have been demonstrated that $70 \%$ of errors occur in the pre-analytical phase which is an important service of laboratory medicine and these errors are possible causes for the sample rejection. The sample rejection ultimately will affect the quality of patient care, delay in diagnosis and treatment, postpone of scheduled operating procedure, increase the patient length of stay in hospital and reduce the customer satisfaction. The identification of errors and highlighting the possible failure modes which have highest frequency will help the clinicians and management to address the areas of process failure.

In Hospitals, two-thirds of important clinical decisions on patient treatment and management are based on laboratory test results. Quality, accuracy, short turnaround time (TAT) are very important in effective laboratory services. The types of laboratory services are classified as pre-analytical, analytical, post-analytical phases based upon time of their presentation. The International Organization for Standardization (ISO) 15189:2012 standard for laboratory 
accreditation defines the pre-analytical phase as "processes that start, in chronological order, from the clinician's request and include the examination request, preparation and identification of the patient, collection of the primary sample(s), and transportation to and within the laboratory, and end when the analytical examination begins". 1 Laboratory specialists have been demonstrated that $70 \%$ of errors occur in the pre-analytical phase which is an important service of laboratory medicine. ${ }^{2}$ If the occurrence of error is manmade then it can always be identified and reduced. Samples are rejected by following the standard rejection criteria in the clinical laboratory, which ultimately will affect the quality patient care, delay in diagnosis and treatment, postpone of scheduled operating procedure, increases the patient length of stay in hospital. A quality and risk assessment tools used to evaluate the possible failure modes are a) Brainstorming, b) Fish-bone diagram to identify the root cause of the problem and the effect it has on the hospital, c) Pareto's chart to illustrate the data as such to find out the areas where there is a need for maximum control and check, need for improvisation or change of process, need to improve the skills ofemployees. d) Failure Mode and Effect Analysis (FMEA) is an aid to calculate Risk Priority Number (RPN) that is the product of Severity Index (S.I), Occurrence Index (O.I), and Detectability Index(D.I).

\section{Need for the study}

Reduction of risk associated with the pre-analytical phase, as one of the most important phases that influences the patient outcome and healthcare costs, is essential for improving total quality and customer satisfaction. Even though the hospital has been acquired NABH accreditation for maintaining standards in providing quality patient care, the hospital wants to evaluate the clinical laboratory services by knowing sample rejection rate as a part of the preparation for the confronting scheduled re-accreditation process in the month of May 2019. As the Hospital consists of only 100 beds providing all kinds of tertiary care, it expects to have least possible failure modes for the sample to get rejected and wants to reduce the sample rejection rate to possibly lower. A strategy to their source detection of Failure modes might be with the use of Healthcare Failure Mode and Effects Analysis (FMEA), fish-bone diagram, Pareto Chart.

\section{Review of Literature}

ZelihaGunnurDikmen et al.conducted a study on "specimen rejection in laboratory medicine: necessary for patient safety?" say that the samples sent to the emergency laboratory were recorded for 1 year in which 453171 samples were received and 27,067 samples were rejected. The most frequent rejection reasons were fibrin clots (28\%) and deficient volume (9\%) for biochemical tests. The ratios of rejected specimens were higher in the EDs (40\%) compared to ICUs $(30 \%)$ and inpatient services $(28 \%)$. By documentation of rejected samples and periodic training of healthcare personnel, there will be a decline insample rejection rate below $2 \%$, improve the total quality management of the emergency laboratory and promote patient safety. ${ }^{3}$

LourensA. Jacobsz et al. conducted a study on "chemistry and hematology sample rejection and clinical impact in a tertiary laboratory" describes that a total of 32,910 specimens were received during the study period, of which 481 were rejected, giving a rejection rate of $1.46 \%$. The main causes for rejection were inappropriate clotting (30\%) and deficient sample volume (22\%). Just $51.7 \%$ of rejected samples were repeated and the average time for a repeat sample to reach the laboratory was around 5days (121h). Examination of patient folders showed that in $40 \%$ of cases the rejection of samples had an impact on patient care. Rejected specimens due to factors which are not in laboratory's control had a definite impact on patient care and can thus affect patient satisfaction. Clinicians should be aware of these factors to prevent such rejections. ${ }^{4}$

Elisabet González Lao et al. conducted a study on "errors of clinical laboratory \& It's impact on patient care" says that the methodology used in this study to identify and estimate the possible failure modes was the Failure mode and effect analysis (FMEA). The Risk Priority Number was used to calculate the critical errors in laboratory services. Based on these results, the risk map is prepared in the clinical laboratory which allows us to identify critical points in all laboratory processes and prioritize the control of this points. ${ }^{5}$

Plebani et al. state that the pre-analytical phase should be subdivided into pre-preanalytical phase and preanalytical phase. The Pre-preanalytical phase includes test request, patient or sample identification, sample collection, handling and transport, whereas the preanalytical phase involves the steps of sample preparation for analysis such as centrifugation and sorting. It has been demonstrated that most blunders happen in the pre-preanalytical phase by healthcare personnel who are not under the control of the laboratory, while the preanalytical phase begins following 
specimen acceptance by the laboratory staff. For the prevention of preanalytical errors, the most reliable approach is to construct a preanalytical standardization. ${ }^{6}$

Nikunj Modi, TejasShahz was conducted a study to compare application of Six Sigma test in Clinical Laboratory along with current technique of Internal quality control and External quality assurance scheme as a quality indicator. The results found that the different sigma value like more than three for plasma glucose, creatinine, total protein, uric acid and serum glutamate pyruvate transferase (SGPT) while less than three for Urea and albumin. To maintain a six sigma is very challenging for the quality management personnel of the hospital, but it will help to improve the quality of the process in the laboratory. ${ }^{7}$

\section{Methodology:-}

This study is based on

Research Study design:

Secondary data review and cross-sectional data analysis for reasons for rejection of sample.

\section{Method of Data Collection:}

Retrospective data is collected from Sample Rejection Register maintained by laboratory for the period of January 2018 to April 2019. Observational data is collected from wards, ER, MICU \& OPD sample collectionroom.

\section{Evaluation technique used:}

A strategy to their source detection of Failure modes might be with the use of Healthcare Failure Mode and Effects Analysis (FMEA), fish- bone diagram, ParetoChart.

Using the clinical laboratory standard Institute (CLSI) ${ }^{8}$ guidelines, FMEA is allowed to identify the potential failure modes, causes \& its effects through a product of 2 variables that are Occurrence Index (O.I) \& Detectability Index (D.I) and by ranking them according to RPN (Risk PriorityNumber).

\section{Stakeholders involved in thestudy}

Stakeholders involved in the study are Laboratory staff, Nursing staff, Housekeeping staff, Pharmacy staff for analyzing Cost of Poor Quality (COPQ).

\section{Criteria for thestudy}

Inclusion criteria:

All the OP and IP Biochemistry \& Hematology samples received in the laboratory

\section{Exclusion criteria:}

1. Samples from outside of NH clinics.

2. Severity Index (S.I) of the potential mode is not considered because it's very difficult to rank severity index without knowing the diagnosis of thepatient.

\section{Pre-analytical Phaseworkflow:}

The clinical laboratory in NH receives the samples for analysis from OP-D sample collection room, IP wards, Emergency room, ICU's, rarely from Operation Theater, outside NH clinics. The pre-analytical phase of clinical laboratory services consists of workflow shown clearly with the help of flowchart (figure no: 1). The International Organization for Standardization defines laboratory error as "failure of a planned action to be completed as intended, or use of a wrong plan to achieve an aim, occurring at any part of the laboratory process, from ordering examinations to reporting results and appropriately interpreting and responding to them". 9 
Figure no1:-Pre-analytical Phase Workflow

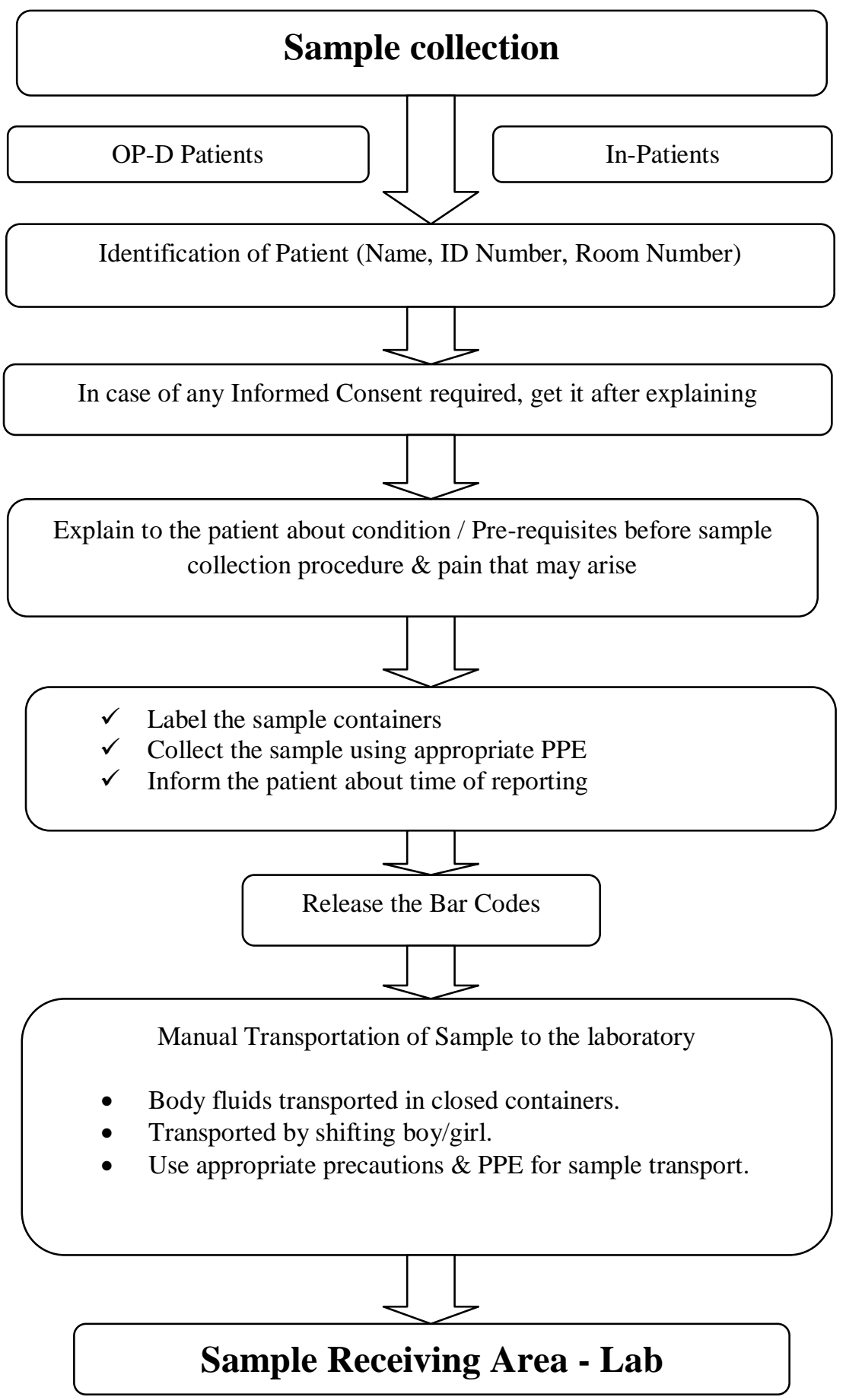

\section{Data analysis}

The total number of Biochemistry and hematology samples (both from OP \& IP-D) received in the laboratory during study period from January 2018 to April 2019 is about 3,81,452 samples. The total number of samples rejected by the laboratory is $182(0.047 \%)$. Out of 182 , the number of samples rejected from the OP-D sample collection room is fortunately nil and where all the 182 samples rejected are from IP-D. The Root Cause Analysis (RCA) is performed to identify all the potential root causes (PRC) during brainstorming and observation and depicted with help of Fish-bone diagram (figure no: 2). These PRC's have been identified by performing retrospective data analysis of past process failure and real time event analysis during observation. 
Figure no2:-Fish-bone diagram

Root Cause Analysis - Fish Bone Diagram

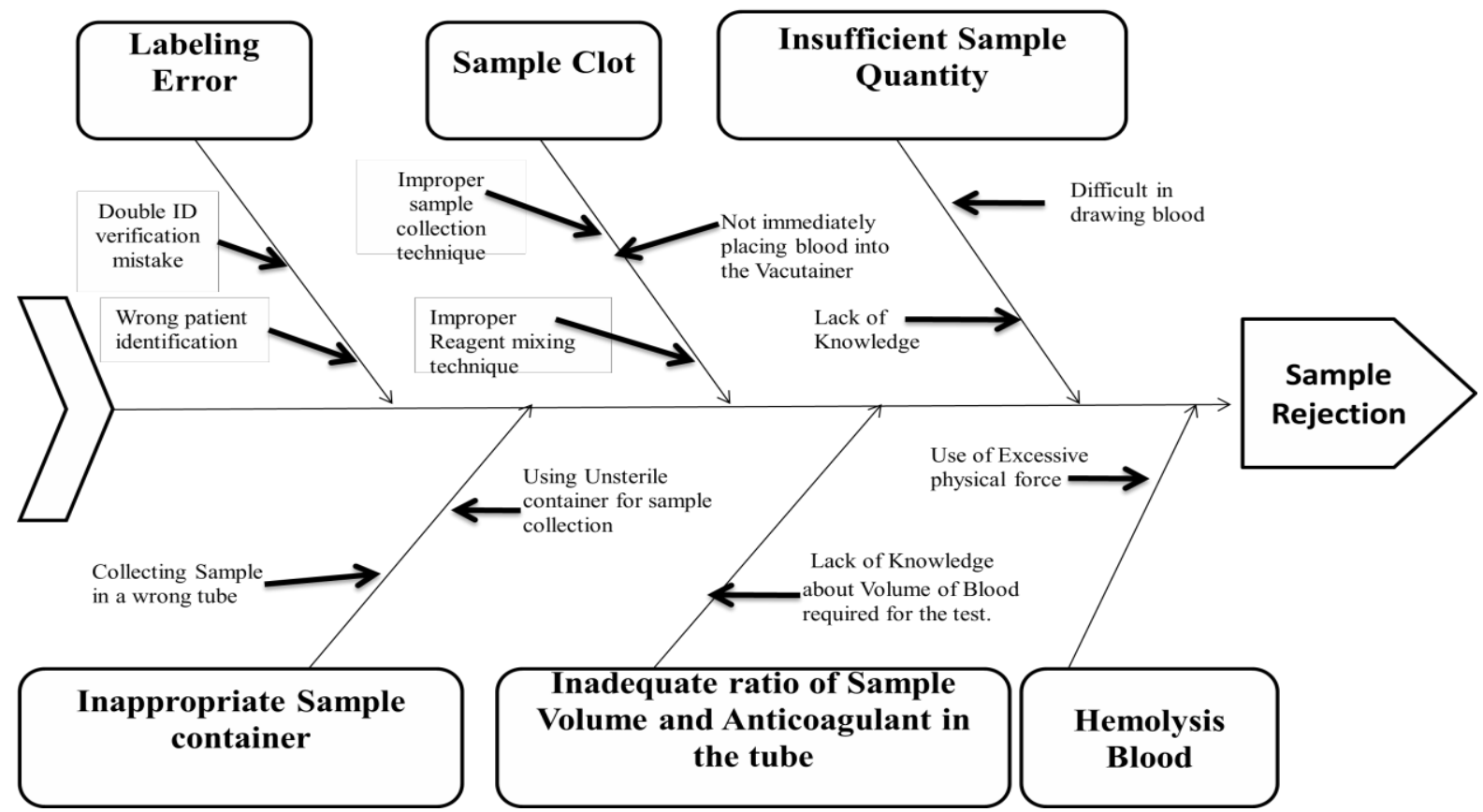

The probability of Failure modes / Pre-analytical errors for the sample to get reject are Sample clot $(44.6 \%)$, insufficient sample quantity $(18.1 \%)$, inappropriate sample Vacutainer or tube (16.4\%), Labeling error $(10.9 \%)$, inadequate ratio of sample volume and anticoagulant $(6.5 \%)$, Hemolysis blood(3.2\%). This data is clearly depicted by using Pareto chart as shown in figure no:3.

Figure no3:-Pareto chart

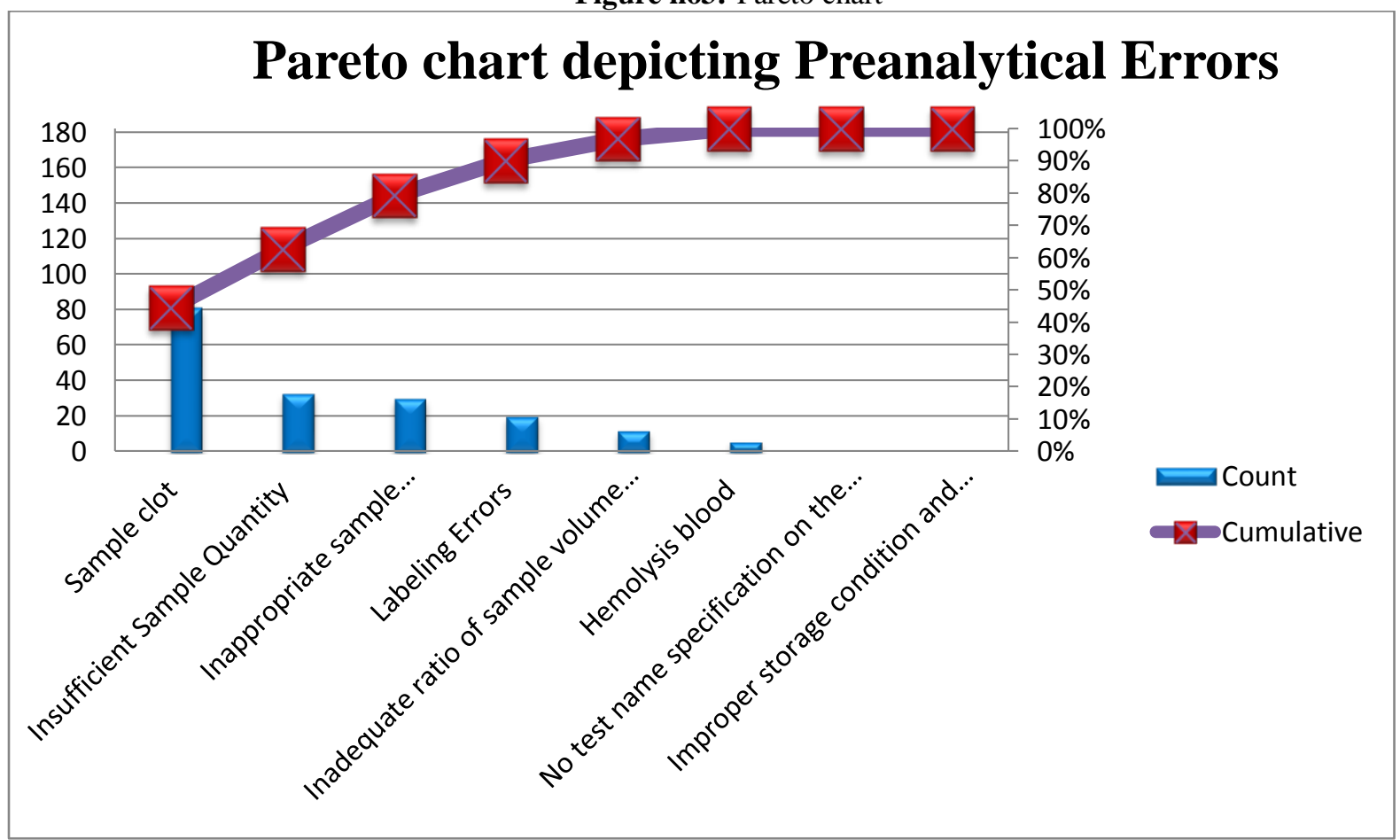


Pareto chart process has begun by identifying all the PRC during Brainstorming (Fish bone diagram). The Pareto principle states that " $80 \%$ of the problems are caused by $20 \%$ of the root causes". Where figure no: 3 , clearly shows that $20 \%$ of PRC's (sample clot, Insufficient sample quantity, Inappropriate sample Vacutainer / tube) are identified as responsible for $80 \%(\mathrm{n}=144$ out of 182) of the process failure occurrence and remaining $80 \%$ of PRC's (Labeling Errors, Inadequate ratio of sample, Hemolysis blood, No test name specification on the requisition form, Improper storage condition and transportation) are responsible for $20 \%(\mathrm{n}=38$ out of 182) of the process failure occurrence. All the PRC's are subsequently used as Failure modes in the FMEA analysis.

In FMEA analysis the Failure modes are ranked according to RPN (product of O.I \& D.I) and the failure mode which have high ranking is highlighted to focus more to reduce it possibly lower.

\begin{tabular}{|c|c|c|c|c|c|c|c|c|}
\hline \multicolumn{9}{|c|}{ Failure Mode Effect Analysis for Sample Rejection (Table no: 3) } \\
\hline $\begin{array}{c}\text { Pha } \\
\text { se }\end{array}$ & $\begin{array}{c}\text { Failure } \\
\text { Mode }\end{array}$ & $\begin{array}{l}\text { Failure Mode } \\
\text { Cause }\end{array}$ & $\begin{array}{c}\text { Failure Mode } \\
\text { effect }\end{array}$ & O. & $\begin{array}{l}\text { D. } \\
\text { I }\end{array}$ & $\begin{array}{c}\mathbf{R P} \\
\mathbf{N}\end{array}$ & $\begin{array}{c}\text { Control } \\
\text { measures } \\
\text { already in } \\
\text { Place }\end{array}$ & $\begin{array}{c}\text { Proposed } \\
\text { Action/Recommendation } \\
\mathrm{s}\end{array}$ \\
\hline \multirow[t]{3}{*}{ 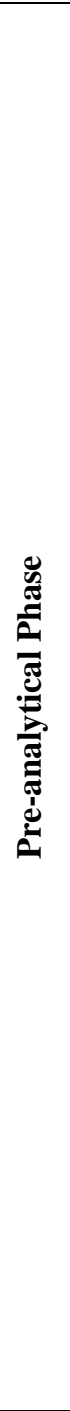 } & $\begin{array}{c}\text { Labeling } \\
\text { error }\end{array}$ & $\begin{array}{l}\text { 1. Double ID } \\
\text { verification } \\
\text { mistake } \\
\text { 2. Wrong } \\
\text { patient } \\
\text { identification } \\
\text { 3. Barcode } \\
\text { Mistake } \\
\text { 4. Blood was } \\
\text { collected by } \\
\text { one } \\
\text { Nurse/Phlebot } \\
\text { omist and } \\
\text { Labeled by } \\
\text { another } \\
\text { nurse/Phleboto } \\
\text { mist. } \\
\text { 5. Incomplete, } \\
\text { Illegible or } \\
\text { Unlabelled } \\
\text { sample. }\end{array}$ & $\begin{array}{l}\text { 1. Delay in } \\
\text { Diagnosis and } \\
\text { Treatment } \\
\text { 2. } \\
\text { Unnecessary } \\
\text { blood draws } \\
\text { 3.Wrong } \\
\text { Treatment } \\
\text { 4. Results } \\
\text { from another } \\
\text { Patient } \\
\text { 5. Results are } \\
\text { useless for the } \\
\text { Patient }\end{array}$ & 5 & $4^{*}$ & 20 & $\begin{array}{l}\text { - Revision } \\
\text { (or) Double } \\
\text { check of } \\
\text { Labeling } \\
\text { Process }\end{array}$ & $\begin{array}{l}\text { - Audit \& feedback of } \\
\text { labeling errors: Real time } \\
\text { event Reporting. } \\
\text { - Only one staff should be } \\
\text { involved in whole process } \\
\text { for one patient (staff who } \\
\text { collects the sample should } \\
\text { be responsible for placing } \\
\text { blood into tube, labeling it } \\
\text { and placing it into cryo- } \\
\text { carry box). }\end{array}$ \\
\hline & $\begin{array}{l}\text { No test } \\
\text { name } \\
\text { specificati } \\
\text { on on the } \\
\text { requisition } \\
\text { form }\end{array}$ & - & - & 0 & 1 & 0 & $\begin{array}{l}\text { - Use of } \\
\text { centralized } \\
\text { Hospital } \\
\text { information } \\
\text { Manageme } \\
\text { nt } \\
\text { system(HI } \\
\text { MS)\& bar- } \\
\text { coding in } \\
\text { Hospital }\end{array}$ & - Effective use of HLIS \\
\hline & $\begin{array}{c}\text { Sample } \\
\text { Clot }\end{array}$ & $\begin{array}{l}\text { 1. Improper } \\
\text { sample } \\
\text { collection } \\
\text { technique }\end{array}$ & $\begin{array}{l}\text { 1. Request for } \\
\text { Repeat } \\
\text { Sample } \\
\text { 2. Delay in }\end{array}$ & 8 & $6^{*}$ & 48 & $\begin{array}{l}\cdot \text { Education } \\
\& \text { training } \\
\text { of } \\
\text { healthcare }\end{array}$ & $\begin{array}{l}\text { - Education \& Training for } \\
\text { newly joined staff about } \\
\text { Hospital Protocol (SOP of } \\
\text { sample collection }\end{array}$ \\
\hline
\end{tabular}




\begin{tabular}{|c|c|c|c|c|c|c|c|}
\hline & $\begin{array}{l}\text { 2. Improper } \\
\text { Reagent } \\
\text { mixing } \\
\text { technique } \\
\text { 3. Incorrect } \\
\text { Sample } \\
\text { Vacutainer/Tu } \\
\text { be } \\
4 \text {. Not } \\
\text { immediately } \\
\text { placing blood } \\
\text { into the } \\
\text { Vacutainer/tub } \\
\text { e after drawing } \\
\text { blood using } \\
\text { syringe. } \\
\text { 5. Very slow } \\
\text { drawing of } \\
\text { blood into a } \\
\text { tube. }\end{array}$ & $\begin{array}{l}\text { Diagnosis and } \\
\text { Treatment } \\
\text { 3. Increase in } \\
\text { Length of stay } \\
\text { in Hospital. } \\
\text { 4. Increase in } \\
\text { related } \\
\text { Healthcare } \\
\text { cost }\end{array}$ & & & & $\begin{array}{l}\text { staff } \\
\text { responsible } \\
\text { for sample } \\
\text { collection } \\
\text { (Demonstra } \\
\text { tion classes } \\
\text { by external } \\
\text { phlebotomi } \\
\text { st). } \\
\text { • Closed } \\
\text { System of } \\
\text { blood } \\
\text { collection } \\
\text { is practiced } \\
\text { only in } \\
\text { OPD } \\
\text { sample } \\
\text { collection } \\
\text { room }\end{array}$ & $\begin{array}{l}\text { \&Transportation). } \\
\text { - Use of sample collection } \\
\text { tray* } \\
\text { - Use of Closed System of } \\
\text { blood collection is } \\
\text { recommended in IP wards. } \\
\text { - Assessment of the } \\
\text { frequency of system errors } \\
\text { caused by sample clot }\end{array}$ \\
\hline $\begin{array}{l}\text { Insufficien } \\
\text { t Sample } \\
\text { Quantity/ } \\
\text { Volume }\end{array}$ & $\begin{array}{l}\text { 1. Untrained } \\
\text { (or) Unskilled } \\
\text { Phlebotomist/ } \\
\text { Nurse } \\
\text { 2. Lack of } \\
\text { Knowledge } \\
\text { about Volume } \\
\text { of Blood } \\
\text { required for } \\
\text { the test. } \\
\text { 3. Difficult in } \\
\text { drawing blood } \\
\text { (Small } \\
\text { children, Old } \\
\text { age, } \\
\text { dehydrated } \\
\text { Patient, } \\
\text { Improper } \\
\text { Selection of } \\
\text { vein). }\end{array}$ & $\begin{array}{l}\text { 1. Double } \\
\text { Prick (or) } \\
\text { Double Injury } \\
\text { to the patient } \\
\text { 2. Increase } \\
\text { TAT for } \\
\text { getting Lab } \\
\text { Reports. } \\
\text { 3. Delay in } \\
\text { Diagnosis and } \\
\text { Treatment. }\end{array}$ & 6 & 6 & 36 & $\begin{array}{l}\cdot \text { Education } \\
\& \text { training } \\
\text { of } \\
\text { healthcare } \\
\text { staff } \\
\text { responsible } \\
\text { for sample } \\
\text { collection } \\
\text { (Demonstra } \\
\text { tion classes } \\
\text { by external } \\
\text { phlebotomi } \\
\text { st). }\end{array}$ & $\begin{array}{l}\text { - Taking help of skilled } \\
\text { and experienced staff in } \\
\text { cases of difficult blood } \\
\text { draw. }\end{array}$ \\
\hline $\begin{array}{c}\text { Inappropr } \\
\text { iate } \\
\text { Sample } \\
\text { container/ } \\
\text { Incorrect } \\
\text { sample } \\
\text { Vacutaine } \\
\text { r }\end{array}$ & $\begin{array}{l}\text { 1. Collecting } \\
\text { Sample in a } \\
\text { wrong tube/ } \\
\text { Vacutainer } \\
\text { 2. Using } \\
\text { Unsterile } \\
\text { container for } \\
\text { sample } \\
\text { collection } \\
\text { 3. Lack of } \\
\text { Knowledge } \\
\text { about } \\
\text { Vacutainers } \\
\text { and its order of } \\
\text { draw }\end{array}$ & $\begin{array}{l}\text { 1. Request for } \\
\text { Repeat } \\
\text { Sample } \\
2 . \\
\text { Misdiagnosis } \\
\text { and Wrong } \\
\text { Treatment }\end{array}$ & 5 & 6 & 30 & $\begin{array}{l}\text { Use if } \\
\text { color coded } \\
\text { sample } \\
\text { Vacutainers }\end{array}$ & $\begin{array}{l}\text { - Copy of guidelines for } \\
\text { order of draw has to be } \\
\text { stick on walls right above } \\
\text { the sample collection tray } \\
\text { in wards }\end{array}$ \\
\hline
\end{tabular}




\begin{tabular}{|c|c|c|c|c|c|c|c|}
\hline $\begin{array}{l}\text { Inadequat } \\
\text { e ratio of } \\
\text { Sample } \\
\text { Volume } \\
\text { and } \\
\text { Anticoagul } \\
\text { ant in the } \\
\text { tube }\end{array}$ & $\begin{array}{l}\text { 1. Lack of } \\
\text { Knowledge } \\
\text { about Volume } \\
\text { of Blood } \\
\text { required for } \\
\text { the test. }\end{array}$ & $\begin{array}{l}\text { 1. Results are } \\
\text { useless for the } \\
\text { Patient care }\end{array}$ & 4 & 4 & 16 & $\begin{array}{l}\text { - Education } \\
\& \text { training } \\
\text { of } \\
\text { healthcare } \\
\text { staff } \\
\text { responsible } \\
\text { for sample } \\
\text { collection }\end{array}$ & $\begin{array}{l}\text { - Use of Closed System of } \\
\text { blood collection is } \\
\text { recommended in IP wards. }\end{array}$ \\
\hline $\begin{array}{l}\text { Hemolysis } \\
\text { Blood }\end{array}$ & $\begin{array}{l}\text { 1. Improper } \\
\text { collection and } \\
\text { forced push of } \\
\text { blood in to } \\
\text { tube using } \\
\text { syringe } \\
\text { 2. Use of } \\
\text { Excessive } \\
\text { physical force } \\
\text { (or) shaking } \\
\text { the tube } \\
\text { vigorously } \\
\text { after collection } \\
\text { of sample. } \\
\text { 3. Drawing } \\
\text { blood } \\
\text { specimens } \\
\text { from an } \\
\text { intravenous } \\
\text { Cannula or } \\
\text { central line. }\end{array}$ & $\begin{array}{l}\text { 1. Request for } \\
\text { Repeat } \\
\text { Sample } \\
\text { 2. Results are } \\
\text { useless for the } \\
\text { Patient care }\end{array}$ & 2 & 8 & 16 & $\begin{array}{l}\text { - Not to } \\
\text { collect } \\
\text { sample } \\
\text { from IV } \\
\text { Cannula } \\
\text { (or) central } \\
\text { line. } \\
\text { Use of } \\
\text { Cryo-carry } \\
\text { boxes for } \\
\text { storage \& } \\
\text { transportati } \\
\text { on. }\end{array}$ & $\begin{array}{l}\text { - Proper storage \& } \\
\text { transportation by Cryo- } \\
\text { carry boxes. } \\
\text { - Use of correct size of } \\
\text { needle gauge } \\
\text { - Audit \& feedback of } \\
\text { Sample collection } \\
\text { procedure: Real time event } \\
\text { Reporting. }\end{array}$ \\
\hline
\end{tabular}




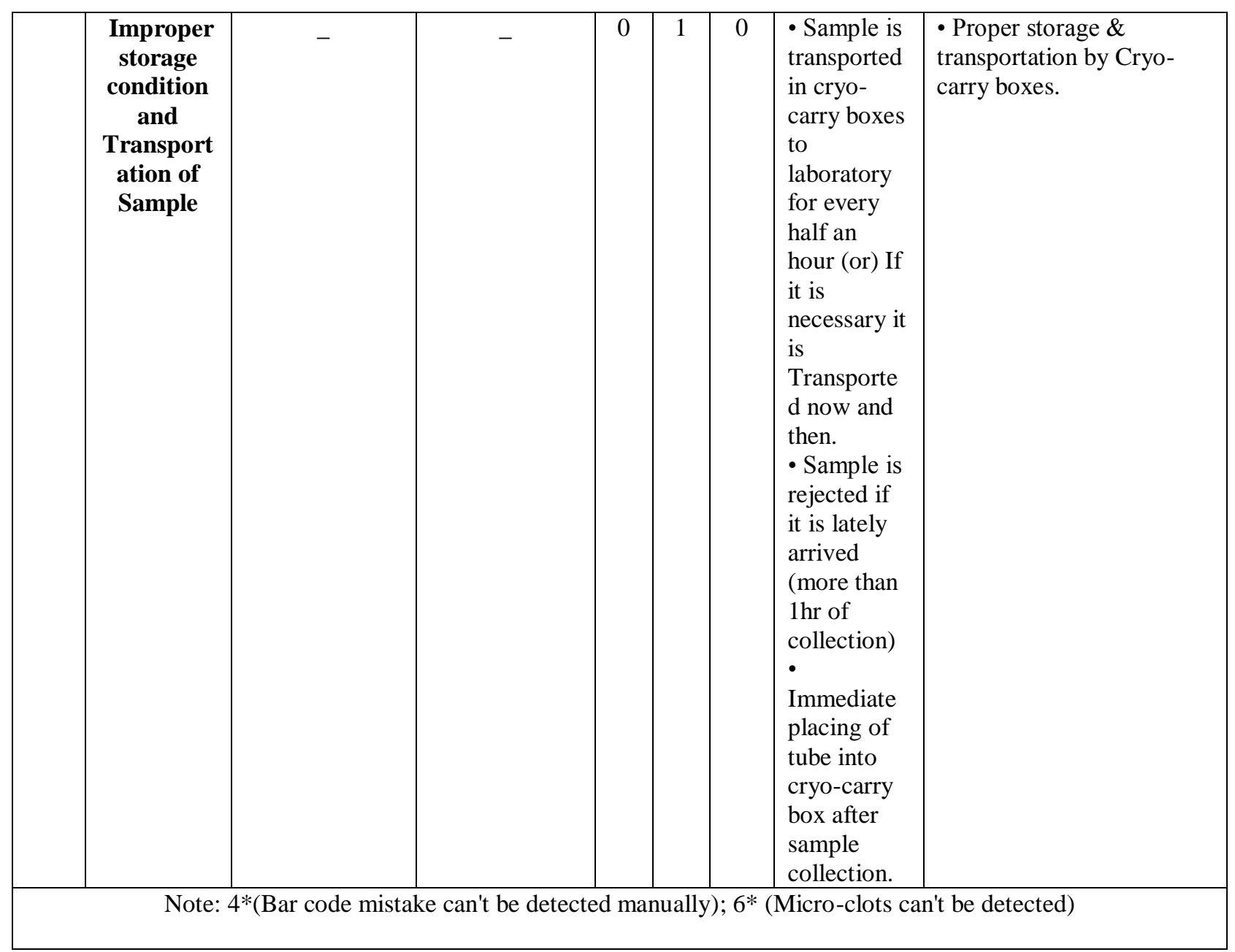

The FMEA (table no: 3) shows that the highest RPN values are for sample clot, Insufficient sample quantity and Inappropriate sample Vacutainer/tube are 48, 36 and 30 respectively. Even though, the RPN values are highest among all identified failure modes, they are less than $50(\mathrm{RPN}<50)$ which indicates that the processes involved are well controlled. However, as suggested by Llopis et al. ${ }^{10}$ and Angeles Gimenez-Marin et al. ${ }^{11}$ given that the potential danger to the patient of such incidents may be very high, so this means some changes and reinforcement of existing process is required to minimize the errors possibly lower.

\section{Conclusion:-}

The overall failure rate/error rate in the pre-analytical phase is $0.047 \%$ which indicates that the process is well controlled. No doubt, if the occurrence of error is manmade then it can always be identified and reduced. The highest rates according to Pareto's Principle \& FMEA analysis are found for the failure modes sample clot, insufficient sample quantity, inappropriate sample Vacutainer / tube ( $n=144$ out of 182) with RPN value of 48, 36 and 30 respectively. Even though, these RPN values are highest among all identified failure modes, they are less than $50(\mathrm{RPN}<50)$ which indicates that the processes involved are well controlled.

\section{References:-}

1. International Organization for Standardization (ISO 15189:2012): medical laboratories: particular requirements for quality and competence. Geneva, Switzerland: International Organization for Standardization; 2012

2. Carraro P, Plebani. Errors in a stat laboratory: Types and frequency 10 years later. Clin Chem. 2007; 53: 133842. http://dx.doi.org/10.1373/clinchem.2007.088344.

3. Dikmen, ZelihaGunnur et al. "Specimen rejection in laboratory medicine: Necessary for patient safety?" Biochemiamedica vol. 25, 3 377-85, 15 oct.2015, doi 10. 11613/BM2015.037. 
4. Jacobsz, L., Zemlin, A., Roos, M., et al. (2011). Chemistry and hematology sample rejection and clinical impact in a tertiary laboratory in Cape Town. Clinical Chemistry and Laboratory Medicine (CCLM), 49(12), pp. 20472050. Retrieved 29 May. 2019, from doi:10.1515/CCLM.2011.743

5. Lao, E.G, Garcia, A.s, Figuerola M B, Moreno. E and Para ire A.H (2017) Errors of clinical Laboratory and Its Impact on Patient Safety, Open Journal of Social Science, 5,243-253.

6. Plebani M. Quality Indicators to Detect Preanalytical Errors in Laboratory Testing. ClinBiochem Rev 2012; 33:85-8.

7. Nikunj Modi, Tejas Shah; Application of Six sigma test in clinical biochemistry laboratory, International journal of research medicine,Int J Res Med. 2017; 6(2); 75-78

8. CLSI. Laboratory Quality Control Based on Risk Management; Approved Guideline. CLSI document. EP23-A. Wayne, PA: Clinical and Laboratory Standards Institute, 2011.

9. Plebani M, Lippi G. To err is human. To misdiagnosis might be deadly. ClinBiochem 2010; 43:1-3.

10. LlopisMA, Trujillo G, Llovet MI, Tarres E, Ibarz M, Biosca C et al. Quality indicators and specifications for key analytical-extranalytical processes in the clinical laboratory. Five years experience using the Six Sigma concept. ClinChem Lab Med 2011; 49:463-70. http://dx.doi.org/10.1515/CCLM.2011.067.

11. Giménez-Marín, Angeles et al. "Pre-analytical errors management in the clinical laboratory." Biochemia media vol.24, (2): 248-57. doi:10.11613/BM.2014.027. 